\title{
Analisis Komparasi Kinerja Keuangan Daerah Kabupaten Nias, Nias Selatan, Nias Barat, dan Nias Utara
}

\author{
Samalua Waoma \\ Program Studi Akuntansi STIE Nias Selatan \\ samaluawaoma@gmail.com
}

\begin{abstract}
Abstrak
Tujuan penelitian ini adalah untuk menganalisis bagaimanakah, adakah perbedaan, dan peringkat berapakah kinerja keuangan Kabupaten Nias, Nias Selatan, Nias Barat, dan Nias Utara tahun 2010-2016 menggunakan rasio derajat desentralisasi, rasio ketergantungan daerah, dan rasio kemandirian keuangan daerah. Metode analisis data yang digunakan adalah analisis rasio, analisis manova dan analisis rata-rata. Berdasarkaan hasil penelitian menunjukkan bahwa kinerja keuangan Kabupaten Nias, Nias Selatan, Nias Barat, dan Nias Utara tahun 2010-2016 menggunakan rasio derajat desentralisasi sangat kurang, rasio ketergantungan daerah sangat baik, dan rasio kemandirian keuangan daerah sangat baik. Adanya perbedaan kinerja keuangan Kabupaten Nias, Nias Selatan, Nias Barat, dan Nias Utara tahun 2010-2016 menggunakan rasio derajat desentralisasi, rasio ketergantungan daerah, dan rasio kemandirian keuangan daerah. Peringkat kinerja keuangan Kabupaten Nias, Nias Selatan, Nias Barat, dan Nias Utara Tahun 2010-2016 menggunakan rasio derajat desentralisasi adalah urutan pertama Kabupaten Nias disusul Kabupaten Nias Selatan, Kabupaten Nias Utara, dan terakhir Kabupaten Nias Barat. Pada rasio ketergantungan keuangan daerah ditempati secara berturut-turut oleh Kabupaten Nias Barat, Kabupaten Nias Utara, Kabupaten Nias Selatan dan terakhir Kabupaten Nias. Pada kemandirian keuangan daerah posisi pertama ditempati oleh Kabupaten Nias selanjutnya Kabupaten Nias Selatan, Kabupaten Nias Utara dan Kabupaten Nias Barat. Diharapkan kepada pemerintah daerah untuk meningkatkan penerimaan PAD secara intensifikasi dan ekstensifikasi. Masyarakat harus mendukung kebijakan yang dibuat oleh pemerintah daerah sesuai kemampuannya dalam membayar pajak dan retribusi daerah.
\end{abstract}

Kata Kunci: Komparasi, Kinerja Keuangan, dan Daerah

Pendahuluan

Sumatera Utara merupakan salah propinsi dari 34 propinsi yang ada di Indonesia yang terdiri dari 33 Kabupaten/Kota. Beberapa kabupaten yang ada tersebut diantaranya Kabupaten Nias, Kabupaten Nias Selatan, Kabupaten Nias
Barat, dan Kabupaten Nias Utara. Keempat Kabupaten tersebut berada pada satu pulau yang disebut dengan Pulau Nias. Berdasarkan Peraturan Presiden Nomor 131 Tahun 2015 keempat kabupaten tersebut di atas masuk dalam kategori daerah tertinggal. Daerah tertinggal adalah daerah kabupaten yang 
wilayah dan masyarakatnya kurang berkembang dibandingkan dengan daerah lain dalam skala nasional dengan kriteria a). Perekonomian masyarakat, b). Sumber daya manusia, c). Sarana dan prasarana, d). Kemampuan keuangan daerah, e). Aksesbilitas, dan f). Karekateristik daerah (Peraturan Pemerintah Nomor 78 Tahun 2004). Berdasarkan pada kriteria di atas tentunya keempat kabupaten tersebut berada pada kriteria kurang atau mungkin sangat kurang.

Kabupaten Nias merupakan kabupaten tertua (induk) disusul dengan kabupaten pemekaran berturut-turut yaitu Kabupaten Nias selatan, Kabupaten Nias Barat, dan Kabupaten Nias Utara. Tercapainya pertumbuhan ekonomi yang tinggi, menurunnya tingkat penganguran dan kemiskinan merupakan gambaran hasil kinerja pemerintah dalam pengelolaan keuangan daerah yang baik (Ani dan Dwirandra, 2014:483). Sedangkan dalam pelaksanaan otonomi daerah, salah satu kriteria untuk mengetahui secara nyata kemampuan daerah dalam mengatur rumah tangganya adalah self supporting didalam bidang keuangan artinya daerah harus mampu untuk menggali sumber-sumber keuangan sendiri serta mengelola dan menggunakan keuangan sendiri yang cukup memadai untuk membiayai penyelenggaraan daerahnya (Halim, 2013). Berikut pertumbuhan ekonomi, tingkat penganguran, kemiskinan, jumlah penduduk, Indeks Pembangunan Manusia (IPM) dan luas wilayah. Tabel 1

Pertumbuhan Ekonomi, Pengangguran, Kemiskinan, Jumlah Penduduk, IPM dan Luas Wilayah

\begin{tabular}{|l|l|c|c|c|r|r|r|}
\hline No & $\begin{array}{c}\text { Nama } \\
\text { Kabupaten }\end{array}$ & $\begin{array}{c}\text { Pertumbuhan } \\
\text { Ekonomi (\%) }\end{array}$ & $\begin{array}{c}\text { Penganggu } \\
\text { ran (\%) }\end{array}$ & $\begin{array}{c}\text { Kemiskinan } \\
\mathbf{( 0 0 0 )} \text { jiwa }\end{array}$ & $\begin{array}{c}\text { Jumlah } \\
\text { Penduduk } \\
\text { (jiwa) }\end{array}$ & IPM & $\begin{array}{c}\text { Luas } \\
\text { Wilayah } \\
\left(\mathbf{k m}^{2}\right)\end{array}$ \\
\hline 1 & Nias & 5,43 & 0,92 & 24,11 & 141.403 & 59,75 & $1.842,51$ \\
\hline 2 & Nias Selatan & 4,46 & 0,40 & 57,75 & 311.319 & 59,14 & $1.825,20$ \\
\hline 3 & Nias Barat & 4,87 & 2.96 & 24,16 & 80.785 & 59,03 & 473,73 \\
\hline 4 & Nias Utara & 5,49 & 4,02 & 41,66 & 135.013 & 60,23 & $1.202,78$ \\
\hline
\end{tabular}

Sumber: Provinsi Sumut Dalam Angka (2017).

Pada tabel 1 di atas pertumbuhan ekonomi tertinggi diraih oleh Kabupaten Nias Utara disusul Kabupaten Nias, Kabupaten Nias barat dan terakhir Kabupaten Nias Selatan. Pengangguran terendah di Kabupaten Nias Selatan disusul Kabupaten Nias, Kabupaten Nias Barat dan tertinggi di Kabupaten Nias Utara. Jumlah jiwa penduduk miskin terbanyak di Kabupaten Nias Selatan disusul Kabupaten Nias Utara, Kabupaten Nias barat dan terendah di Kabupaten Nias.

Dalam Pasal 28 ayat (2) UndangUndang Nomor 33 Tahun 2004 menyatakan bahwa setiap kebutuhan pendanaan diukur secara berturut-turut dengan jumlah penduduk, luas wilayah, indeks kemahalan kontruksi, PDRB perkapita, dan IPM. Berdasarkan tabel 1 di atas jumlah penduduk terbanyak adalah Kabupaten Nias Selatan disusul Kabupaten Nias, Kabupaten Nias Utara dan terakhir Kabupaten Nias Barat. Dalam hal PDRB tertinggi Kabupaten Nias, diikuti Kabupaten Nias Selatan, Kabupaten Nias Utara dan terakhir Kabupaten Nias Barat. Kabupaten Nias Utara menduduki urutan pertama untuk IPM disusul Kabupaten Nias, Kabupaten Nias Selatan dan terakhir Kabupaten Nias Barat. Berdasarkan pada kondisi di atas apakah kinerja keuangan juga 
mengikuti urutan pada beberapa indikator di atas?.

Salah satu kriteria daerah tertinggal adalah kemampuan keuangan daerah. Anggaran Pendapatan dan Belanja Daerah (APBD) merupakan cerminan kinerja dan kemampuan keuangan daerah dalam membiayai dan mengelola penyelenggaraan pemerintah daerah dalam satu tahun anggaran pada daerah masing-masing. Hal ini dapat dilihat pada ketercapaian realisasi APBD setiap tahunnya. Penilaian terhadap pengelolaan keuangan daerah dapat dilihat dari hasil analisis terhadap APBD yang telah ditetapkan dan dilaksanakan (Halim, 2002:126-127). Berikut ini anggaran dan realisasi pendapatan dan belanja daerah empat kabupaten yang ada dikepulauan Nias: Tabel 2

Realisasi APBD Tahun 2012-2016 (dalam ribu rupiah)

\begin{tabular}{|c|c|c|c|c|c|c|}
\hline No & $\begin{array}{c}\text { Nama } \\
\text { Kabupaten }\end{array}$ & 2012 & 2013 & 2014 & 2015 & 2016 \\
\hline \multirow{5}{*}{1} & Nias: & & & & & \\
\hline & Anggaran (Rp) & 442.130 .182 & 516.664 .960 & 523.374 .415 & 560.862 .393 & 843.699 .193 \\
\hline & Realisasi (Rp) & 526.349 .128 & 579.405 .980 & 515.836 .196 & 691.021 .859 & 818.455 .989 \\
\hline & Realiasi (\%) & 119,05 & 112,14 & 98,56 & 123,21 & 97,01 \\
\hline & Rata-rata $(\%)$ & \multicolumn{5}{|c|}{109,99} \\
\hline \multirow{5}{*}{2} & \multicolumn{6}{|l|}{ Nias Selatan: } \\
\hline & Anggaran (Rp) & 623.007 .839 & 835.720 .278 & 829.114 .321 & 783.248 .764 & 1.093 .581 .486 \\
\hline & Realisasi (Rp) & 648.206 .150 & 768.231 .763 & 643.149 .408 & 814.895 .232 & 1.008 .885 .854 \\
\hline & Realiasi (\%) & 104,05 & 91,92 & 77,57 & 104,04 & 92,26 \\
\hline & Rata-rata (\%) & \multicolumn{5}{|c|}{93,97} \\
\hline \multirow{5}{*}{3} & \multicolumn{6}{|l|}{ Nias Barat: } \\
\hline & Anggaran (Rp) & 343.115 .035 & 368.658 .123 & 397.053 .134 & 440.730 .510 & 599.969 .151 \\
\hline & Realisasi (Rp) & 362.914 .671 & 415.015 .662 & 373.104 .473 & 465.951 .796 & 534.832 .477 \\
\hline & Realiasi (\%) & 105,77 & 112,57 & 93,97 & 105,72 & 89,14 \\
\hline & Rata-rata (\%) & \multicolumn{5}{|c|}{101,43} \\
\hline \multicolumn{7}{|c|}{ Nias Utara: } \\
\hline \multirow{4}{*}{4} & Anggaran (Rp) & 331.731 .672 & 483.682 .036 & 495.620 .848 & 537.580 .395 & 761.769 .895 \\
\hline & Realisasi (Rp) & 426.397 .873 & 496.343 .554 & 490.265 .502 & 599.606 .675 & 679.245 .604 \\
\hline & Realiasi (\%) & 128,54 & 102,62 & 98,92 & 111,54 & 89,17 \\
\hline & Rata-rata (\%) & \multicolumn{5}{|c|}{106,16} \\
\hline
\end{tabular}

Sumber: Statistik Keuangan Pemerintah Daerah Kabupaten/Kota (diolah)

Berdasarkan tabel 2 di atas menunjukkan realisasi APBD setiap tahunnya selama 5 (lima) tahun. Bila diurutkan rata-rata pencapaian realisasi APBD maka Kabupaten Nias berada pada urutan pertama, disusul Kabupaten Nias Utara, Kabupaten Nias Barat dan Kabupaten Nias Selatan. Apakah urutan ini juga merupakan urutan kinerja keuangan daerahnya?.

Pertanggungjawaban APBD akan terlihat pada Laporan Keuangan Pemerintah Daerah (LKPD) setiap tahunnya. Informasi yang terkandung dalam laporan pertanggungjawaban atas laporan keuangan pemerintah daerah dapat digunakan sebagai 
indikator untuk mengukur kinerja keuangan pemerintah daerah (Abdullah, 2013). Kualitas LKPD akan terlihat pada karekteristik kualitatif. Karakteristik kualitatif laporan keuangan adalah ukuranukuran normatif (relevan, andal, dapat dibandingkan dan dapat dipahami) yang perlu diwujudkan dalam informasi akuntansi

Tabel 3

Opini BPK Terhadap LKPD Tahun 2012-2016

\begin{tabular}{|c|l|r|r|r|r|r|r|}
\hline No & Nama Kabupaten & $\mathbf{2 0 1 2}$ & $\mathbf{2 0 1 3}$ & $\mathbf{2 0 1 4}$ & $\mathbf{2 0 1 5}$ & $\mathbf{2 0 1 6}$ & $\mathbf{2 0 1 7}$ \\
\hline 1 & Nias & TMP & WDP & WDP & WDP & WDP & WDP \\
\hline 2 & Nias Selatan & TMP & TMP & TMP & TMP & TMP & TMP \\
\hline 3 & Nias Barat & TMP & TMP & TMP & WDP & TMP & TMP \\
\hline 4 & Nias Utara & TMP & TMP & WDP & WDP & WDP & WDP \\
\hline
\end{tabular}

Sumber: BPK RI

Pada tabel di atas ada 2 jenis opini BPK terhadap LKPD yaitu WDP dan TMP (disclaimer). Kabupaten Nias mendapatkan WDP lima tahun berturut-turut dan satu tahun TMP, Kabupaten Nias Utara mendapatkan empat tahun WDP dan dua tahun TMP, Kabupaten Nias Barat hanya satu tahun WDP dan lima tahun TMP dan Kabupaten Nias Selatan hanya memperoleh TMP tanpa WDP selama enam tahun. Apakah ada perbedaan kinerja keuangan daerah yang memperoleh WDP dengan TMP?.

Berdasarkan permasalahan yang tersebut di atas maka rumusan masalah dalam penelitian ini adalah:

1. Bagaimana kinerja keuangan Kabupaten Nias, Nias Selatan, Nias Barat, dan Nias Utara tahun 2010-2016 menggunakan rasio derajat desentralisasi, rasio ketergantungan daerah, dan rasio kemandirian keuangan daerah.

2. Adakah perbedaan kinerja keuangan Kabupaten Nias, Nias Selatan, Nias Barat, dan Nias Utara tahun 2010-2016 menggunakan rasio derajat desentralisasi, rasio ketergantungan agar dapat memenuhi tujuannya (Komite Standar Akuntansi pemerintah, 2005:KK10). Penilaian kinerja LKPD ini di lakukan oleh Badan Pemeriksa Keuangan (BPK). Berikut ini hasil pemeriksaan LKPD yang dilaksanakan oleh BPK dalam bentuk opini ditujukan pada tabel 3 . 
pendapatan daerahnya (Hamzah, 2008). Menurut Nazir, (2005:58) Komparasi yaitu sejenis penelitian deskriptif yang ingin mencari jawaban secara mendasar tentang sebab akibat, dengan menganalisis faktorfaktor penyebab terjadinya ataupun munculnya suatu fenomena tertentu. Pendapat lain penelitian komparasi penelitian yang berusaha menemukan persamaan dan perbedaan tentang benda, tentang ide, atau suatu porsedur kerja (Arikunto dalam Sudijono, 2010:274).

Kinerja Keuangan daerah adalah tingkat pencapaian dari suatu hasil kerja dibidang keuangan daerah yang meliputi penerimaan dan belanja daerah dengan menggunakan indikator keuangan yang ditetapkan melalui suatu kebijakan atau ketentuan perundang-undangan selama satu periode (Sucipto, 2007). Menurut Arifin (2004) ada beberapa analisis rasio keuangan di dalam pengukuran kinerja keuangan daerah yang dikembangkan berdasarkan data keuangan yang bersumber dari APBD yakni tingkat kemandirian pembiayaan, tingkat ketergantungan dan desentralisasi fiskal. Hasil analisis APBD merupakan informasi yang penting untuk membuat kebijakan dalam pengelolaan keuangan daerah dan menilai keberhasilan pemerintah daerah dalam mengelola keuangannya.

Pengukuran kenerja keuangan

Pemerintah Daerah dilakukan untuk memenuhi 3 tujuan yaitu (1). Memperbaiki kinerja pemerintah, (2). Membantu mengalokasikan sumber daya dan pembuatan keputusan, dan (3). Mewujudkan pertanggungjawaban publik dan memperbaiki komunikasi kelembagaan (Mardiasmo, 2002: 121).

\section{Metode Penelitian}

Jenis penelitian yang digunakan adalah penelitian kualitatif deskriptif dan kuantitaf statistik. Jenis data adalah data skunder yang berasal dari Laporan realisasi APBD tahun 2010-2016.

Metode analisis data yang digunakan berturut-turut sesuai dengan rumusan masalah adalah analisis rasio, Analysis of Variance (anova) dan analisis rata-rata. Untuk menganalisis kinerja keuangan menggunakan analisi rasio yang terdiri dari (Mahmudi, 2010:142):

1. Derajat Desentralisasi $=$ $\frac{\text { Pendapatan Asli Daerah }}{\text { Total Pendapatan Daerah }} \times 100 \%$

2. Rasio Ketergantungan Daerah $=$ $\frac{\text { Pendapatan Transfer }}{\text { Total Pendapatan Daerah }} \times 100 \%$

3. Rasio Kemandirian Keuangan Daerah $=$ $\frac{\text { Pendapatan Asli Daerah }}{\text { Transfer Pusat+Propinsi }} \times 100 \%$

Untuk menganalisis perbedaan dan besarnya perbedaan kinerja keuangan setiap kabupaten menggunakan analisis Multivariate Analysis of Variance (Manova). Manova merupakan suatu teknik dependensi guna mengukur perbedaan dua atau lebih variabel dependen yang bersifat metrik yang berdasar pada sederet variabel independen bersifat non-metrik (Hair, 2010). Pendapat lainnnya Manova adalah metode statistik untuk mengeksplorasi hubungan diantara beberapa variabel independen yang berjenis kategorial (bisa data nominal atau ordinal) dengan beberapa variabel dependen yang berjenis metrik (bisa data interval atau rasio dengan tujuan untuk mengetahui apakah ada perbedaan yang nyata pada variabel-variabel dependen antar-anggota grup (Lane, 2016, 114-122). Untuk membandingkan kinerja keuangan daerah dilakukan dengan langkahlangkah sebagai berikut:

a. Menentukan hipotesis penelitian yang terdiri dari:

Ho : Tidak ada perbedaan kinerja keuangan. 


\section{Ha : Terdapat perbedaan kenerja keuangan.}

b. Menentukan ktriteria pengambilan keputusan yaitu: Ho diterima apabila Sig $\geq 5 \%$ dan Ho ditolak apabila Sig $<5 \%$.

Untuk menganalisis peringkat kinerja keuangan daerah masing-masing kabupaten digunakan rata-rata hitung yaitu menjumlahkan seluruh setiap rasio keuangan dibagi dengan jumlah tahun anggaran dan realiasi APBD setiap kabupaten.

Tabel 4

Rasio Derajat Desentralisasi Fiskal

\begin{tabular}{|c|r|c|c|c|c|c|c|c|}
\hline \multirow{2}{*}{ Tahun } & \multicolumn{3}{|c|}{ Kab. Nias } & \multicolumn{2}{c|}{ Kab. Nias Selatan } & \multicolumn{2}{c|}{ Kab. Nias Barat } & \multicolumn{2}{c|}{ Kab. Nias Utara } \\
\cline { 2 - 9 } & \multicolumn{1}{c|}{$\%$} & Kriteria & $\%$ & Kriteria & $\%$ & Kriteria & $\%$ & Kriteria \\
\hline 2010 & 5.99 & Sangat Kurang & 3.05 & Sangat Kurang & 0.74 & Sangat Kurang & 1.08 & Sangat Kurang \\
\hline 2011 & 4.68 & Sangat Kurang & 4.69 & Sangat Kurang & 0.98 & Sangat Kurang & 2.01 & Sangat Kurang \\
\hline 2012 & 7.28 & Sangat Kurang & 2.25 & Sangat Kurang & 1.26 & Sangat Kurang & 1.94 & Sangat Kurang \\
\hline 2013 & 9.66 & Sangat Kurang & 1.50 & Sangat Kurang & 2.21 & Sangat Kurang & 2.16 & Sangat Kurang \\
\hline 2014 & 12.62 & Kurang & 1.99 & Sangat Kurang & 2.76 & Sangat Kurang & 2.24 & Sangat Kurang \\
\hline 2015 & 10.26 & Kurang & 1.85 & Sangat Kurang & 3.11 & Sangat Kurang & 2.82 & Sangat Kurang \\
\hline 2016 & 10.12 & Kurang & 1.61 & Sangat Kurang & 2.94 & Sangat Kurang & 3.51 & Sangat Kurang \\
\hline Rerata & 8.66 & Sangat Kurang & 2.42 & Sangat Kurang & 2.00 & Sangat Kurang & 2.25 & Sangat Kurang \\
\hline
\end{tabular}

Sumber: data diolah (2018)

Pada tabel 4 di atas dapat dilihat penyerahan kewenangan fiskal dari pemerintah pusat kepada daerah otonom berada secara umum masih sangat kurang yang artinya bahwa keuangan daerah otonom masih banyak yang berasal dari dana pusat atau provinsi. Hal ini disebabkan oleh minimnya kontribusi PAD setiap daerah otonom terhadap pendapatan yang diterima oleh daerah. Kabupaten Nias Selatan, Kabupaten Nias Barat dan Kabupaten Nias Utara berada pada kriteria sangat kurang

Tabel 5

Rasio Ketergantungan Keuangan Daerah

\begin{tabular}{|c|c|c|c|c|c|c|c|c|}
\hline \multirow{2}{*}{ Tahun } & \multicolumn{2}{|c|}{ Kab. Nias } & \multicolumn{2}{c|}{ Kab. Nias Selatan } & \multicolumn{2}{c|}{ Kab. Nias Barat } & \multicolumn{2}{c|}{ Kab. Nias Utara } \\
\cline { 2 - 9 } & $\%$ & Kriteria & $\%$ & Kriteria & $\%$ & Kriteria & $\%$ & Kriteria \\
\hline 2010 & 74.24 & Sangat Tinggi & 85.81 & Sangat Tinggi & 84.20 & Sangat Tinggi & 90.89 & Sangat Tinggi \\
\hline 2011 & 82.03 & Sangat Tinggi & 81.33 & Sangat Tinggi & 88.86 & Sangat Tinggi & 85.53 & Sangat Tinggi \\
\hline 2012 & 83.74 & Sangat Tinggi & 86.85 & Sangat Tinggi & 94.86 & Sangat Tinggi & 91.91 & Sangat Tinggi \\
\hline 2013 & 89.61 & Sangat Tinggi & 88.37 & Sangat Tinggi & 93.09 & Sangat Tinggi & 88.46 & Sangat Tinggi \\
\hline
\end{tabular}

2016 berada pada kriteria kurang yang artinya pada tahun tersebut agak lebih baik dari tahun-tahun sebelumnya maupun sesudahnya.

Rasio ketergantungan keuangan daerah dihitung dengan membagikan pendapatan transfer terhadap total pendapatan yang diterima oleh daerah. Rasio ketergantungan keuangan daerah dapat dilihat pada tabel berikut: 


\begin{tabular}{|c|c|l|l|l|l|l|l|l|}
\hline 2014 & 83.57 & Sangat Tinggi & 91.01 & Sangat Tinggi & 90.82 & Sangat Tinggi & 89.82 & Sangat Tinggi \\
\hline 2015 & 76.09 & Sangat Tinggi & 77.18 & Sangat Tinggi & 82.09 & Sangat Tinggi & 84.72 & Sangat Tinggi \\
\hline 2016 & 74.70 & Sangat Tinggi & 71.03 & Sangat Tinggi & 82.41 & Sangat Tinggi & 82.20 & Sangat Tinggi \\
\hline Rerata & 80.57 & Sangat Tinggi & 83.08 & Sangat Tinggi & 88.05 & Sangat Tinggi & 87.65 & Sangat Tinggi \\
\hline
\end{tabular}

Sumber: data diolah (2018)

Pada tabel 5 di atas menujukkan ketergantungan keuangan daerah otonom secara keseluruhan berada pada kriteria sangat tinggi. Hal ini disebabkan karena ketidakmampuan pemerintah daerah dalam meningkatkan PAD. Apabila hal ini terus berlanjut maka dapat dipastikan bahwa menjadi salah satu permasalahan terkait otonomi daerah dan desentralisasi keuangan daerah bagi daerah otonom maupun pusat. Akibat lainnya adalah beban keuangan pusat yang semakin besar untuk pembiayaan daerah otonom. Menurut Djalil (2014)

Tabel 6

Rasio Kemandirian Keuangan Daerah

\begin{tabular}{|c|r|c|c|c|c|c|c|c|}
\hline \multirow{2}{*}{ Tahun } & \multicolumn{2}{|c|}{ Kab. Nias } & \multicolumn{2}{c|}{ Kab. Nias Selatan } & \multicolumn{2}{c|}{ Kab. Nias Barat } & \multicolumn{2}{c|}{ Kab. Nias Utara } \\
\cline { 2 - 9 } & \multicolumn{1}{c|}{$\%$} & Kriteria & $\%$ & Kriteria & $\%$ & Kriteria & $\%$ & Kriteria \\
\hline 2010 & 6.38 & Sangat Baik & 3.15 & Sangat Baik & 0.74 & Sangat Baik & 1.10 & Sangat Baik \\
\hline 2011 & 4.92 & Sangat Baik & 4.92 & Sangat Baik & 0.99 & Sangat Baik & 2.05 & Sangat Baik \\
\hline 2012 & 7.85 & Sangat Baik & 2.30 & Sangat Baik & 1.28 & Sangat Baik & 1.97 & Sangat Baik \\
\hline 2013 & 10.69 & Baik & 1.52 & Sangat Baik & 2.26 & Sangat Baik & 2.21 & Sangat Baik \\
\hline 2014 & 14.44 & Baik & 2.04 & Sangat Baik & 2.84 & Sangat Baik & 2.29 & Sangat Baik \\
\hline 2015 & 11.43 & Baik & 1.88 & Sangat Baik & 3.21 & Sangat Baik & 2.90 & Sangat Baik \\
\hline 2016 & 11.26 & Baik & 2.27 & Sangat Baik & 3.29 & Sangat Baik & 3.64 & Sangat Baik \\
\hline Rerata & 9.57 & Sangat Baik & 2.58 & Sangat Baik & 2.09 & Sangat Baik & 2.31 & Sangat Baik \\
\hline
\end{tabular}

Sumber: data diolah (2018)

Kemampuan pemerintah daerah dalam membiayai sendiri kegiatan pemerintahan, pembangunan dan pelayanan pada masyarakat ditujukkan pada tabel 6 di atas keempat kabupaten di atas secara umum berada pada kriteria baik dan sangat baik yang artinya daerah tersebut secara keuangan daerah dapat mandiri. Akan tetapi bila dilihat dari kontribusi PAD terhadap pendapatan daerah sangat rendah. Hal ini menyebabkan setiap pembelanjaan yang dilakukan masih bergantung pada dana pusat maupun provinsi dalam bentuk dana perimbangan. Ketika besarnya derajat keteragantungan daerah yang tinggi terhadap pusat dalam jangka panjang akan mengakibatkan pemerintah pusat mengalami financial distress (tekanan berat keuangan) karena kesulitan menanggung beban keuangan daerah.

Rasio kemandirian keuangan daerah dapat dilihat dengan membagi PAD dengan transfer pusat ditambah provinsi. Perhitungan rasio ini dapat dilhat pada tabel 6 dibawah ini. belanja daerahnya lebih banyak berasal dari dana perimbangan daripada PAD menyebabkan terjadinya fenomena flypaper effect (efek kertas layang). Menurut Sukriy dan halim (2004:1140) flypaper effect adalah suatu kondisi yang terjadi saat Pemda merespon belanja lebih banyak dengan menggunakan dana transfer berupa DAU dari pada menggunakan sumber dana kemampuan sendiri.

Ada tidaknya perbedaan kinerja keuangan daerah keempat kabupaten di atas dapat dilihat pada tabel 7 dibawah ini: 
Tabel 7

Tests of Between-Subjects Effec

\begin{tabular}{|l|l|r|r|r|}
\hline \multirow{4}{*}{ Variabel Independen } & \multicolumn{1}{|c|}{ Variabel Dependen } & $\begin{array}{c}\text { Type III Sum } \\
\text { of Squares }\end{array}$ & $\begin{array}{c}\text { Mean } \\
\text { Square }\end{array}$ & Sig \\
\hline \multirow{4}{*}{ Desentralisasi Fiskal } & Kabupaten Nias & 39,670 & 9,918 & 0,000 \\
\cline { 2 - 5 } & Kabupaten Nias Selatan & 6,229 & 1,557 & 0,000 \\
\cline { 2 - 5 } & Kabupaten Nias Barat & 2,957 & 0,739 & 0,000 \\
\cline { 2 - 5 } & Kabupaten Nias Utara & 0,868 & 0,217 & 0,000 \\
\hline \multirow{3}{*}{$\begin{array}{l}\text { Ketergantungan Keuangan } \\
\text { Daerah }\end{array}$} & Kabupaten Nias & 121,588 & 30,397 & 0,000 \\
\cline { 2 - 5 } & Kabupaten Nias Selatan & 51,013 & 12,753 & 0,000 \\
\cline { 2 - 5 } & Kabupaten Nias Barat & 68,110 & 17,027 & 0,000 \\
\cline { 2 - 5 } $\begin{array}{l}\text { Kemandirian Keuangan } \\
\text { Daerah }\end{array}$ & Kabupaten Nias Utara & 24,527 & 6,132 & 0,000 \\
\cline { 2 - 5 } & Kabupaten Nias & 57,179 & 14,295 & 0,000 \\
\cline { 2 - 5 } & Kabupaten Nias Selatan & 7,082 & 1,770 & 0,000 \\
\cline { 2 - 5 } & Kabupaten Nias Barat & 3,185 &, 796 & 0,000 \\
\cline { 2 - 5 } & Kabupaten Nias Utara &, 913 &, 228 & 0,000 \\
\hline
\end{tabular}

Sumber: Olahan (2018)

Dari tabel 7 di atas dapat dilihat bahwa variabel dependen terhadap variabel terdapat nilai signifikansi yang menunjukkan nilai $0,000<5 \%$ yang artinya Ho ditolak. Hal ini berarti ada perbedaan kinerja keuangan antara Kabupaten Nias, Kabupaten Nias Selatan, Kabupaten Nias Barat dan Kabupaten Nias Utara berdasarakan desentralisasi fiskal, radio ketergantungan keuangan daerah dan rasio kemandirian keuangan daerah.

Peringkat kinerja keuangan Kabupaten Nias, Nias Selatan, Nias Barat, dan Nias Utara Tahun 2010-2016 menggunakan rasio derajat desentralisasi, rasio ketergantungan daerah, dan rasio kemandirian keuangan daerah dapat dilihat pada tabel 4, 5 dan 6. Hal perhitungan rata-rata rasio desentralisasi fiskal menujukkan bahwa urutan pertama Kabupaten Nias $(8,66)$ disusul Kabupaten Nias Selatan (2,42\%), Kabupaten Nias Utara $(2,25 \%)$ dan terakhir Kabupaten Nias Barat $(2,00 \%)$. Rata-rata perhitungan rasio ketergantungan keuangan daerah menunjukkan ketergantungan keuangan daerah terhadap dana perimbangan ditempati secara berturut-turut oleh Kabupaten Nias Barat (88,05\%), Kabupaten Nias Utara $(87,65 \%)$, Kabupaten Nias Selatan $(83,08 \%)$ dan terakhir Kabupaten Nias hanya $(80,57 \%)$. Kemandirian keuangan daerah posisi pertama ditempati oleh Kabupaten Nias $(9,57 \%)$ selanjutnya Kabupaten Nias Selatan $(2,58)$, Kabupaten Nias Utara $(2,31)$ dan Kabupaten Nias Barat (2,09\%).

\section{Kesimpulan dan Saran}

Berdasarkan pada pembahasan di atas dapat ditarik kesimpulan bahwa:

1. Kinerja keuangan Kabupaten Nias, Nias Selatan, Nias Barat, dan Nias Utara tahun 2010-2016 menggunakan rasio derajat desentralisasi sangat kurang, rasio ketergantungan daerah sangat baik, dan rasio kemandirian keuangan daerah sangat baik.

2. Adanya perbedaan kinerja keuangan Kabupaten Nias, Nias Selatan, Nias Barat, dan Nias Utara tahun 2010-2016 menggunakan rasio derajat desentralisasi, rasio ketergantungan 
daerah, dan rasio kemandirian keuangan daerah.

3. Peringkat kinerja keuangan Kabupaten Nias, Nias Selatan, Nias Barat, dan Nias Utara Tahun 2010-2016 menggunakan rasio derajat desentralisasi adalah urutan pertama Kabupaten Nias disusul Kabupaten Nias Selatan Kabupaten Nias Utara dan terakhir Kabupaten Nias Barat. Rasio ketergantungan keuangan daerah ditempati secara berturut-turut oleh Kabupaten Nias Barat, Kabupaten Nias Utara, Kabupaten Nias Selatan dan terakhir Kabupaten Nias hanya. Kemandirian keuangan daerah posisi pertama ditempati oleh Kabupaten Nias selanjutnya Kabupaten Nias Selatan, Kabupaten Nias Utara dan Kabupaten Nias Barat.

Diharapkan kepada pemerintah daerah untuk meningkatkan penerimaan PAD secara intensifikasi dan ekstensifikasi. Masyarakat harus mendukung kebijakan yang dibuat oleh pemrintah daerah sesuai kemampuannya dalam membayar pajak dan retrubusi daerah.

\section{Daftar Pustaka}

Abdullah, Sukriy dan Halim, Abdul. 2004. Pengaruh Dana Alokasi Umum (DAU) dan Pendapatan Asli Daerah (PAD) terhadap Belanja Pemerintah Daerah: Studi Kasus Kabupaten/Kota di Jawa dan Bali. Proceeding Simposium Nasional Akuntansi VI. 16-17 Oktober 2003. Surabaya.

Abdullah, Syukriy. 2013. Analisis Kinerja Keuangan Pemerintah Daerah. Blog: http://syukriy.wordpress.com.

Diakses tanggal 18 Juni 2018.

Ani, Ni Luh Nana Putri dan Dwiranda A.A.N.B. (2014) Pengaruh Kinerja Keuangan Daerah Pada Pertumbuhan Ekonomi, Pengangguran dan Kemiskinan Kabupetan dan Kota. E-
Jurnal Akuntansi: Universitas Udayana.

Arifin, Johar. 2004. Analisis Laporan Keuangan Berbasisi Komputer. Jakarta: Elex Media Komputindo.

Badan Pusat Statistik. (2005-2017). Statistik Keuangan Pemerintah Kabupaten/Kota. Jakarta: Badan Pusat Statistik Indonesia.

Badan Pusat Statistik. (2017). Provinsi Sumatera Utara Dalam Angka 2017. Jakarta: Badan Pusat Statistik Indonesia.

Djalil, Rizal. 2014. Ketergantungan Pemda Atas Dana Perimbangan Sangat Tinggi. Berita Online: Antara New Jawa Timur. Diakses tanggal 12 Juli 2018.

Hair, J. F. et al. 2010. Multivariate Data Analysis: A Global Perspective. New Jersey: Pearson Prentice Hall.

Halim, Abdul. 2002. Akuntansi Sektor Publik Akuntansi Keuangan Daerah. Edisi Ke-3. Jakarta: Salemba Empat.

Hamzah, Ardi. 2008. Analisi Kinerja Keuangan Terhadap Pertumbuhan Ekonomi, Pengangguran dan Kemiskinan: Pendekatan Analisis Jalur (Studi pada 29 Kabupaten dan 9 Kota di Provinsi Jawa Timue Periode 2001-2006. Simposium Nasional Akuntansi XI.

Komite Standar Akuntansi Pemerintahan, 2005. Peraturan Pemerintah Nomor 24 Tahun 2005 tentang Standar Akuntansi Pemerintahan.

Lane, D.M. 2016. The Assumption of Sphericity in Repeated-Measures Design: What it means anda what to do when its is violated. The Quantitative Methods for Psychology, 12.

Mahmudi (2010). Manajemen Keuangan Daerah. Jakarta: Erlangga. 
Mardiasmo, 2002. Otonomi dan Manajemen Keuangan Daerah Untuk Menyongsong Pelaksanaan Otomoni Daerah 2001. HIMMEP, Yogyakarta.

Nazir, Mohamad. 2005. Metode Penelitian. Jakarta: Ghalia Indonesia.

Peraturan Pemerintah Nomor 78 Tahun 2004 tentang Percepatan Pembangunan Daerah Tertinggal.

Peraturan Presiden Nomor 131 Tahun 2015 tentang Penetapan Daerah Tertinggal Tahun 2015-2019

Sucipto, 2007. Penilaian Kinerja Keuangan. Jurnal Akuntansi Sumatera Utara Medan.

Sudijono, Anas. 2010. Pengantar Statistik Pendidikan. Jakarta: Raja Grafindo Persada.

Undang-Undang Nomor 33 Tahun 2004 tentang Perimbangan Keuangan Antara Pemerintah Pusat dan Pemerintah daerah. 